\title{
Framework Development of Serious Game-Based Instrument for Malay Language Early Literacy Assessment
}

\author{
Rohani Azizi,2, Helmi Norman1,3*, Norazah Nordin1, Fatin Nabilah Wahid1, Ruslina Ibrahim1 \\ ${ }^{1}$ Faculty of Education, Universiti Kebangsaan Malaysia (UKM), Bangi, Selangor, Malaysia \\ ${ }^{2}$ Examination Syndicates, Ministry of Education, Kuala Lumpur, Malaysia \\ ${ }^{3}$ Center for Teaching and Learning Technologies, UKM, Bangi, Selangor, Malaysia \\ Email: ^helmi.norman@ukm.edu.my
}

How to cite this paper: Aziz, R., Norman, H., Nordin, N., Wahid, F. N., \& Ibrahim, R. (2019). Framework Development of Serious Game-Based Instrument for Malay Language Early Literacy Assessment. Creative Education, 10, 3235-3242.

https://doi.org/10.4236/ce.2019.1012247

Received: October 21, 2019

Accepted: November 27, 2019

Published: November 30, 2019

Copyright $\odot 2019$ by author(s) and Scientific Research Publishing Inc. This work is licensed under the Creative Commons Attribution International License (CC BY 4.0).

http://creativecommons.org/licenses/by/4.0/

(c) (i) Open Access

\begin{abstract}
Literacy achievement is important because it is the underpinning skills that sustain an individual's competencies in early education. However, most of assessment instrument nowadays are in the form of traditional summative assessment. The emerging assessment instrument in recent evolution of technology allows teachers, educators and assessment workers to seek for better approaches in evaluating and assessing students' achievement. While the traditional assessment methods are gradually being transformed into informal and formative assessment methods, an establishment of an alternative assessment framework is needed to accommodate the transformation. Therefore, the aim of this study is to establish the framework development of a Serious Game-Based Instrument for early literacy student assessment. The study used the Focus Group Discussion (FGD) approach to determine the appropriate gamification features of Serious Games and develop the serious game-based assessment framework. For that purposed, 17 experts from different fields of studies were involved in the FGD session. The findings were analyzed using descriptive analysis. This study concludes by highlighting the proposed framework of the Serious Game-Based Literacy Assessment by verifying gamification features and literacy constructs needed for the development of Serious Games of Early Literacy Student Assessment.
\end{abstract}

\section{Keywords}

Serious Games, Assessment Framework, Early Literacy, Literacy Assessment, Serious Game-Based Instrument Framework 


\section{Introduction}

Emerging technologies can be integrated to support student needs in alternative assessment. As mentioned by (Prensky, 2001) nowadays, student generation of digital natives that have spent their entire lives with gadgets and technological tool, computers, video games, cell phones, video cams and all sort of technological need an up-to-date approach to challenge their concentration and enhance their ability in learning. The Ministry of Education Malaysia has initiated three major strategies for ICT implementation in education (Ministry of Finance Malaysia, 2001). The first strategy is to emphasize and enable ICT utilized for all students to decrease the existing digital gap between schools. The second strategy refers to the function of ICT as an effective teaching and learning tool. Parallel to these notions, Ministry of Education Malaysia has again come up with the new rules to overcome the issue of summative types of assessment for early primary students aged 7 to 9 as well as to enforce the effective implementation of formative assessment in school.

\section{Overview}

\subsection{The Concept of Serious Games}

Serious games are designed to have an impact on the target audience (Bellotti, Kapralos, Lee, Moreno-Ger, \& Berta, 2013) which is beyond the pure entertainment aspect (Bellotti, Kapralos, Lee, Moreno-Ger, \& Berta, 2013; Coovert, Winner, Bennett, \& Howard, 2017); to make formal education more exciting and engaging via enhancement of pedagogical and assessment approaches in technological innovation (Arnab et al., 2012) and an attractive tool for education and training (Coovert, Winner, Bennett, \& Howard, 2017). Therefore, Serious Games is one of the alternative platforms to perform formative and real time assessment for student. The concept of Serious Games first raised from the concept of making a game as mixed reality or media to conveys objective meaning throughout the process (Hashim, Rafiq, \& Md Yunus, 2019; Marsh, 2011).

\subsection{The Concept of Alternative Assessment}

The terms of performance-based, formative, alternative, and authentic assessment have been used interchangeably by the researchers and educators. Yet, it concludes a meaning of assessment performed different approaches of traditional, or formal examination, or standardized test. The concept of assessment using more innovative and up-to-date methods has been stated by (Tapp \& Martin, 2014). It is based on the concept that the kinds and forms of assessment and innovation are needed in the field of assessment and testing in order to be consistent with the 21 st century learning style changes. As such, digital assessment is based on the need to provide an alternative to future assessments in line with technological advances (Bennett, Dawson, Bearman, Molloy, \& Boud, 2017; Luckin, Clark, Avramides, Hunter, \& Oliver, 2017; Khan, Aziz, \& Stapa, 2019). Three generations of digital assessments as previously stated by (Bennett, Gard- 
ner, Cartledge, Ramnath, \& Council, 2017); The first generation uses designs based on paper-pencil assessments; The next generation is the generation that will be using new formats including multimedia based responses, automated item builds and scoring automatically; while the next generation is a generation that implements complex simulations and smart tutoring applications and artificial intelligence.

\subsection{The Underpinning Issues of Literacy Assessment}

According to the United Nations Children's Fund (2012), while more and more children are attending school worldwide, many of them drop out or fail to meet minimum standards of learning. In addition, statistics showed that of the world's 650 million children of primary school age, 120 million do not reach Grade 4; another 130 million reach Grade 4 but fail to achieve a minimum level of learning. Meanwhile, the UNESCO Institute for Statistics (UIS) 2016 data on literacy have shown that although literacy has been high on the development agenda over the past decades, yet 750 million adults which two-thirds of whom are women are still lack basic reading and writing skills. Similarly, literacy performance of primary students in Malaysia has shown the huge disparity of the results for K7-K9 student's screening test on language literacy compared to K12 student's achievement test.

\section{Method}

The study was conducted in Focus Group Discussion (FGD) technique. 17 experts from various fields of study were involved in the FGD session. The procedure begins by gathering empirical studies related to gamification features and literacy assessment framework from academic literature repositories. The elements and constructs gathered, later were discussed and classified into several section and subsection respectively. Experts then determined the suitable and appropriate game elements or features as well as literacy constructs to be implemented in the development of Serious Games for Malay Language Literacy Assessment. The findings of the discussion were analyzed using descriptive and thematic analysis (Figure 1).

\section{Results}

\subsection{Assessment Element's Framework}

Results indicate various construct proposed based on literature reviewed (Table $1)$.

\subsection{Gamification and Multimedia Element's Framework}

The game and multimedia elements need to be appropriately implemented in the design of the Serious Games-based Assessment. Therefore, the elements were listed from the literature to be discussed and finalized by experts in the FGD session as well. This is conducted to define a certain practical element, to match the 

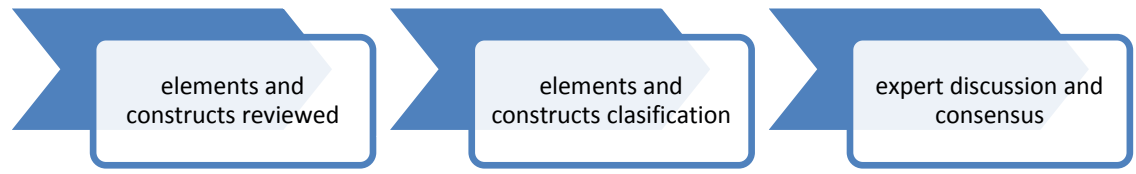

Figure 1. Focus group discussion (FGD) procedure.

Table 1. Assessment framework element by expert's consensus.

\begin{tabular}{|c|c|c|}
\hline No. & Items & Formative Gamification Test \\
\hline 1. & Type of Instrument & Objective (Interactive) \\
\hline 2. & Type of Item & Multi-type Objective \\
\hline 3. & Number of Item & 28 items \\
\hline \multirow{6}{*}{5.} & \multirow{6}{*}{ Total Marks } & $\begin{array}{c}60 \text { Marks; } \\
\text { Level 1: } 10 \text { marks }\end{array}$ \\
\hline & & Level 2: 10 marks \\
\hline & & Level 3: 12 marks \\
\hline & & Level 4: 14 marks \\
\hline & & Level 5: 14 marks \\
\hline & & Total reward score: 70 points \\
\hline 4. & Type of Task & Individual task \\
\hline 5. & Time & 15 - 20 minutes \\
\hline \multirow{2}{*}{6.} & \multirow{2}{*}{ Construct Assessed } & 6 Construct of Knowledge \\
\hline & & Technological application skill \\
\hline \multirow[b]{2}{*}{8.} & \multirow[b]{2}{*}{ Context Assessed } & 2 level of Cognitive Taxonomy \\
\hline & & $\begin{array}{l}\text { Information processes skill, } \\
\text { Psychomotor skill }\end{array}$ \\
\hline 9. & Marking Style & Analytic, Dichotomous \\
\hline
\end{tabular}

construct of knowledge in assessment framework element proposed, then establish a serious games application, and finally efficiently save and maintain student's achievement by designing and implementing Serious Games-based Assessment for literacy assessment.

Therefore, there are five elements of multimedia and gamification was discussed and finalized to get the expert consensus in establishing the foundation of Serious Games-based Assessment proposed for early literacy assessment framework. The five elements are as follows;

- Multimedia elements

- Game elements

- Genre

- Reward element

- Platform option

Table 2 showed gamification elements accepted by the experts to be embedded in the development of Serious Games Malay Language Literacy Assessment. These seven gamification elements were accepted in consideration of the complexity of 
Table 2. Game elements/features.

\begin{tabular}{ccc}
\hline Game elements for Malay Language Literacy Assessment of Serious Games & FGD Result \\
\hline 1. & Rules and regulation & accepted \\
2. & Repitation & accepted \\
3. & Narative & accepted \\
4. & Problem solving & accepted \\
5. & Achievement & accepted \\
6. & Reward & accepted \\
7. & Report & accepted \\
\hline
\end{tabular}

the literacy instrument develops. Therefore, experts agreed that these gamification elements may be discarded during the development process based on the instrumentation develop by the content experts of Malay Language Literacy.

Table 3 showed the reward elements agreed by the experts. Seven reward elements proposed and discussed among experts; Leaderboards, Certificates and/or Badges, Points, Collectibles, Course Currency, Virtual Raffle Tickets, Keys and/or Rarities. Five were accepted by the panel of experts while another two; Course Currency and Virtual Raffle Tickets were discarded as they were less suitable for target games user.

\section{Discussion}

The emerging categories of game features may represent various game-based learning framework and varied ways of combining assessment elements with game elements (Azman \& Farhana Dollsaid, 2018). The study attempted to provide serious game assessment features and taxonomy derived from a comprehensive analysis of both assessment and game elements. Game, multimedia and assessment elements were grouped to categories, encompassing a collection of assessments, game and multimedia elements to be used in designing a game for early literacy assessment purposes. It is perceived that the elements will help instructional designers and game developers to better discern types of assessment element with game and multimedia elements. Therefore, based on expert consensus, the serious game-based assessment framework was outlined as follows (Figure 2).

Thus, a framework for the design of serious game-based assessment, based on six components is proposed. Each component provides its own analytical angle. Basic assumptions underlying the framework are that serious game-based assessment development project is more likely to succeed if the assessment objectives and game element have been clearly established in the development process. As such, the establishment of assessment and game elements are in the right direction if the game designer has carefully thought about how the serious game's desired elements can be grounded in the framework, and if the serious game observes well-established instructional design principles. 
Table 3. Gamification elements (reward).

\begin{tabular}{ccc}
\hline Reward element for Malay Language Literacy Assessment of Serious Games & FGD Result \\
\hline 1. & Leaderboards & accepted \\
2. & Certificates and/or Badges & accepted \\
3. & Points & accepted \\
4. & Collectibles & accepted \\
5. & Course Currency & discarded \\
6. & Virtual Raffle Tickets & discarded \\
7. & Keys and/or Rarities & accepted \\
\hline
\end{tabular}

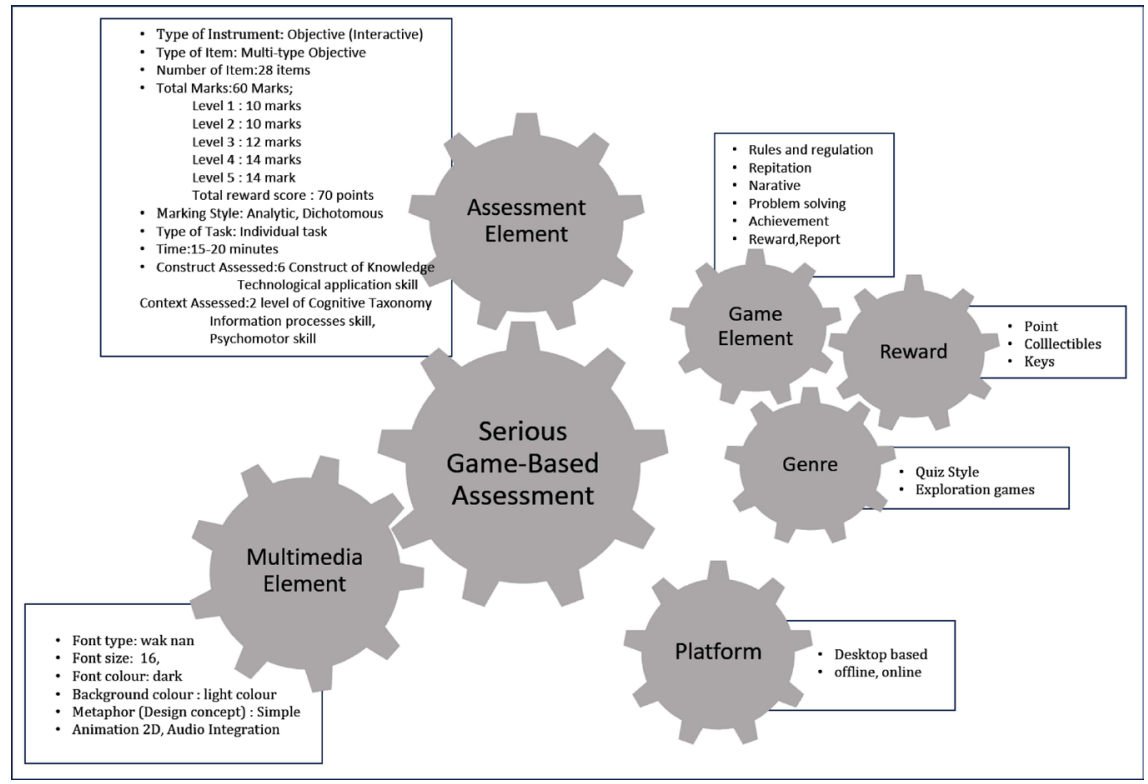

Figure 2. Serious game-based assessment framework for early literacy assessment.

To summarize, the framework proposed helps the serious game designers and serious game developers be deliberate and intentional about the design choices they make. The framework is aimed for thinking about additions or modifications to the game's elements that are intended to make serious games achieve the assessments' objectives in informal context; or at least to spot situations where design decisions may need to be traded off with assessment objectives and serious game objectives accordingly, which sometimes is a reasonable thing to do to meet the serious game-based assessment goals.

The framework developed through the FGD research technique is implemented in the development of serious game-based assessment proposed. For the implementation, the initial prototyping is done using GDevelop gaming software, in which assessment element and game element were blended accordingly.

\section{Conclusion}

The study has presented how Serious Games can be used in educational settings 
and how Serious Games can be integrated as an alternative assessment form to bring out the assessment objective in such informal context. In carrying out real time assessment, it is recommended that the instrument be designed and developed with appropriate game elements. As the proposed framework was done, several suggestions are recommended for future research. Objectively, serious game-based assessment in early literacy should focus on three key elements of serious game design: 1 ) the use of various storylines and assessments element to enhance user engagement, 2) increased use of game elements that facilitate the transfer of knowledge and skills in real-time contexts, 3) the use of different platform options in maximizing the user accessibility, and 4) the use of learning analytics or network diagrams (e.g. social network analysis) for learning assessment. Finally, several key areas of design considerations should be considered by researchers when they design serious games for certain target groups proposed to provide a valuable supplementary tool for an alternative assessment. In sum, it is hoped that this study could assist future educators and researchers interested on investigations of serious games as an alternative format of assessments to suit the needs of fourth Industrial Revolution in educational settings (Nordin, Norman, \& Hamdan, 2018; Adnan \& Ritzhaupt, 2018; Dogan, Norman, Alrobai, Jiang, Nordin, \& Adnan, 2019; Andersen, Na-songkhla, Hasse, Nordin, \& Norman, 2018).

\section{Acknowledgements}

This research is funded by the Translational MRUN Rakan-RU Program Grant (Grant No. MRUN-RAKAN RU-2019-003/2) and Dana Pecutan Penerbitan FPend (Grant No. PP-FPEND-2019).

\section{Conflicts of Interest}

The authors declare no conflicts of interest regarding the publication of this paper.

\section{References}

Adnan, N. F., \& Ritzhaupt, A. D. (2018). Software Engineering Design Principles Applied to Instructional Design: What Can We Learn From Our Sister Discipline? TechTrends, 62, 77-94. https://doi.org/10.1007/s11528-017-0238-5

Andersen, B. L., Na-songkhla, J., Hasse, C., Nordin, N., \& Norman, H. (2018). Perceptions of Authority in a Massive Open Online Course: An Intercultural Study. International Review of Education, 64, 221-239. https://doi.org/10.1007/s11159-018-9708-Z

Arnab, S. et al. (2012). Framing the Adoption of Serious Games in Formal Education. Electronic Journal of e-Learning, 10, 159-171.

Azman, H., \& Farhana Dollsaid, N. (2018). Applying Massively Multiplayer Online Games (MMOGs) in EFL Teaching. Arab World English Journal, 9, 3-18. https://doi.org/10.24093/awej/vol9no4.1

Bellotti, F., Kapralos, B., Lee, K., Moreno-Ger, P., \& Berta, R. (2013). Assessment in and of Serious Games: An Overview. Advances in Human-Computer Interaction, 2013, Ar- 
ticle ID: 136864 https://doi.org/10.1155/2013/136864

Bennett, J. G., Gardner, R., Cartledge, G., Ramnath, R., \& Council, M. R. (2017). Second Grade Urban Learners: Preliminary Findings for a Computer-Assisted, Culturally Relevant, Repeated Reading Intervention. Education and Treatment of Children, 40, 145-185. https://doi.org/10.1353/etc.2017.0008

Bennett, S., Dawson, P., Bearman, M., Molloy, E., \& Boud, D. (2017). How Technology Shapes Assessment Design: Findings from a Study of University Teachers. British Journal of Educational Technology, 48, 672-682. https://doi.org/10.1111/bjet.12439

Coovert, M. D., Winner, J., Bennett, W., \& Howard, D. J. (2017). Serious Games Are a Serious Tool for Team Research. International Journal of Serious Games, 4, 41-55 https://doi.org/10.17083/ijsg.v4i1.141

Dogan, H., Norman, H., Alrobai, A., Jiang, N., Nordin, N., \& Adnan, A. (2019). A Web-Based Intervention for Social Media Addiction Disorder Management in Higher Education: Quantitative Survey Study. Journal of Medical Internet Research, 21, e14834. https://doi.org/10.2196/14834

Hashim, H., Rafiq, R. M., \& Md Yunus, M. (2019). Improving ESL Learners' Grammar with Gamified-Learning. Arab World English Journal, No. 5, 41-50. https://doi.org/10.24093/awej/call5.4

Khan, A. B. M. A., Aziz, M. S. A., \& Stapa, S. H. (2019). Examining the Factors Mediating the Intended Washback of the English Language School-Based Assessment: Pre-Service ESL Teachers' Accounts. Pertanika Journal of Social Sciences \& Humanities, 27, 51-68.

Luckin, R., Clark, W., Avramides, K., Hunter, J., \& Oliver, M. (2017). Using Teacher Inquiry to Support Technology-Enhanced Formative Assessment: A Review of the Literature to Inform a New Method. Interactive Learning Environments, 25, 85-97. https://doi.org/10.1080/10494820.2015.1121152

Marsh, T. (2011). Serious Games Continuum: Between Games for Purpose and Experiential Environments for Purpose. Entertainment Computing, 2, 61-68.

https://doi.org/10.1016/j.entcom.2010.12.004

Ministry of Finance Malaysia (2001). Economic Report 2001/2002: 63-77.

Nordin, N., Norman, H., \& Hamdan, F. (2018). Quality Education with Instructional Design via Massive Open Online Courses. Advanced Science Letters, 24, 2541-2545. https://doi.org/10.1166/asl.2018.11000

Prensky, M. (2001). On the Horizon. Horiz. Libr. Hi Tech News, 9, 12-13.

Tapp, D., \& Martin, L. (2014). We Do Not Like Old Fashioned Exams: The Innovative Use of Alternative Assessments on a Law Degree with a Foundation Year. Innovative Practice in Higher Education, 2, 1-10. 